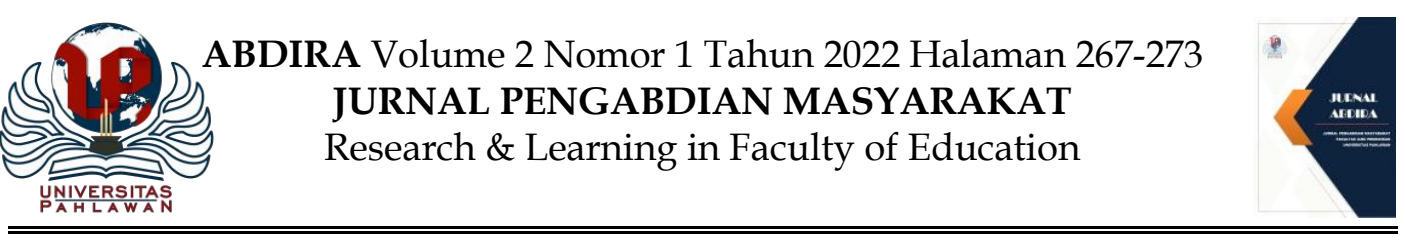

\title{
Pembuatan Video YouTube Channel untuk Pembelajaran Bahasa Inggris di Madrasah Aliyah Kelas X
}

\author{
Awaluddin Syamsu' ${ }^{1}$, Hadijah ${ }^{2}$ \\ Program Studi Pendidikan Bahasa Inggris, Universitas Muslim Indonesia \\ e-mail: awaluddin.syamsu@umi.ac.id
}

\begin{abstract}
Abstrak
Pandemi Covid-19 mengguncang dunia pendidikan Indonesia. Sistem pembelajaran harus dilakukan secara online. Siswa yang dulunya terbiasa belajar dikelas kini harus belajar di rumah. Setelah kasus pandemi sudah berkurang, maka siswa sudah mulai kembali bersekolah akan tetapi dengan berbagai pembatasan. Sehingga cara belajar yang menggabungkan antara online dan offline menjadi hal baru dalam dunia pendidikan terutama ditingkat madrasah. YouTube Channel menjadi salah satu solusi blended learning dimana siswa bisa menonton video pembelajarannya dirumah dan di dalam kelas. Pengabdian ini membuat video yang sesuai dengan konteks siswa Madrasah Aliyah kelas $\mathrm{X}$ yang menjadi objek pengabdian kami. Pengabdian ini menggunakan metode pedampingan kepada 17 siswa dan 2 guru Bahasa Inggris. Adupun hasilnya menunjukkan bahwa banyak hal yang harus dipertimbangkan dalam pembuatan video akan tetapi durasi yang singkat, menarik dan sesuai dengan kurikulum sekolah adalah tiga hal yang paling penting. Hasil dari pengabdian ini akan digunakan oleh pihak sekolah dan menjadi acuan dalam pengebangan video pembelajaran di YouTube Channel.
\end{abstract}

Kata Kunci: Video, YouTube Channel, Pembelajaran Bahasa Inggris

\begin{abstract}
The Covid-19 pandemic has impacted Indonesian's educational system. The learning system must be conducted online. Students who used to study in class currently have to study at home. After the pandemic cases declined, students have started to return to school but with various restrictions. One of the solutions of the situation is to combine online and offline which is a new thing in Indonesia's education for senior high school students. YouTube Channel is one of the blended learning solutions where students can watch their learning videos at home and in class. The created videos were in accordance with the context of the $X$ grade of Madrasah Aliyah students who are the objects of our social service program. This social service used the mentoring method to 17 students and 2 English teachers. The results show that there are many things that must be considered in making a video but the most import are short duration, interesting display and in accordance with the school curriculum. The results of this social service will be used by the school and become a reference in developing learning videos on the YouTube Channel
\end{abstract}

Keyword: Video, YouTube Channel, English learning 


\section{PENDAHULUAN}

Covid-19 telah memaksa pendidikan dilakukan secara online. Tak terasa, sudah 2 tahun lebih pendidikan mulai dari tingkat SD sampai dengan tingkat yang tertinggi yaitu perkuliahan dilakukan secara online. Pelaksanaan belajar mengajar secara online ini banyak memberikan dampak positif dan negatif. Salah satu dampak positifnya adalah bahwa guru dan murid saat ini telah mengenal sistem pembelajaran hybrid. Akan tetapi dampak positifnya menimbulkan berbagai masalah yang membutuhkan penyelesaian.

Sistem pendidikan Indonesia terus mengikuti perkembagan dunia pendidikan terutama dalam pengabungan kelas biasa dan technologi pembelajaran digital. Danchikov at. Al (2021) mengatakan bahwa pembelajaran gabungan ini masih akan terus digunakan dalam waktu yang lama. Bahkan perkembagan dunia pendidikan dalam 10 tahun terakhir sangat pesat dan telah digunakan tidak hanya pada tingkat universitas akan tetapi juga pada tingkat sekolah menengah dan sekolah dasar dan hal ini mengubah cara belajar mengajar karena peralatan belajar online yang semakin mudah didapatkan, akses internet bisa diperoleh dengan mudah, lingkungan belajar online, dan beberapa applikasi atau alat belajar yang memungkinkan penggunaannya dalam bentuk kolaborasi (Selwyn et al., 2017). Akan tetapi Sekolah memiliki tingkat adaptasi yang berbeda Karena perbedaan tingkat integrasi teknologi digital disistem pembelajaran (Starkey, 2020). Hal ini tentusaja sangat dipengaruhi oleh kebijakn sekolah.

Banyak orang mulai dari siswa sampai kepada orang tua siswa merasa bahwa pembelajaran online ini kurang efektif. Hal ini disebabkan karena ketidaksiapan oleh berbagai pihak mulai dari pemerintah, sekolah, guru, murid dan orang tua, untuk melaksanakan sistem pembelajaran ini. Dampaknya adalah banyak keluhan yang telah disampaikan oleh pihak sekolah, guru, murid dan orang tua. Mereka berpikir bahwa anak-anak mereka tidak mempelajari apapun lewat sistem pembelajaran online ini. Bahkan yang mengerjakan pekerjaan rumah adalah keluarga mulai dari orang tua, saudara atau orang lain. Laporan dari UNESCO (2020) mengatakan bahwa tidak semua siswa berusia remaja memiliki kemampuan untuk menggunakan teknologi pembelajaran online yang masih terasa asing sementara yang lainnya hanya tetap berusaha untuk mengikuti perkembagan ini dengan berbagai keterbatasan.

Pembelaran online ini menjadi sesuatu yang sulit oleh banyak siswa apa lagi di usia ini mereka berada dalam kondisi mental yang belum stabil. Oleh karena itu masa ini adalah masa sangat penting untuk menja motivasi siswa termasuk dalam belajar(Eccles et al., 1997). Akan tetapi badai covid 19 yang tibatiba dating di akhir tahun 2019 membuat banyak guru tidak siap merubah sistem pebeljaran mereka. Sehingga pembelajaran mereka kurang efektif, hal ini disebabkan karena sebagian besar guru belum memiliki pengalaman mengjar secara online, atau bahkan belum pernah mendapatkan pelatihan terkait pembelajaran online (Chiu, 2017; \& Ingvarson et al., 2005) 
Dalam konteks pembelajaran online di tempat pengabdian masyarakat dapat kami laporkan bahwa ada banyak kendala lain yang dihadapi oleh siswa seperti kendala jaringan yang tidak stabil, kendala kuota yang kadang tiba-tiba habis di saat pembelajaran sedang berlangsung, biaya pulsa yang terkadang sulit untuk dipenuhi oleh siswa dan orang tuanya.

Seperti pengalaman penulis, bahwa sistem pembelajaran dengan menggunakan YouTube sangat disenangi oleh berbagai siswa. Salah satu hal yang menyebabkan metode ini disenangi adalah bahwa siswa bisa membukanya diwaktu luangnya atau kapan saja mereka inginkan.

Selain itu, jika setelah menonton, siswa belum memahaminya maka mereka bisa memutarnya kembali tanpa menghabiskan banyak kuota. Penghematan kuota juga bisa dilakukan dengan mengurangi kualitas dari gambarnya seperti misalnya menurunkan kualitasnya dari 720 menjadi 360 atau bahkan 240. Kualitas 360 ini adalah kualitas gambar yang menengah yang semua tulisan dengan font dan ukuran yang normal itu bisa terbaca dengan baik. Akan tetapi jika misalnya tulisannya agak besar maka kualitas 240 itu sudah bisa digunakan.

Adapun bagi guru, salah satu manfaat terbesarnya adalah materi yang telah di-upload bisa digunakan berulang-ulang. Tidak hanya digunakan berulang-ulangpada kelas yang berbeda pada tahun yang sama, bisa juga digunakan pada kelas yang berbeda di tahun yang akan datang. Selain itu, jika seorang guru telah mengajarkan materi ke-3 lalu kemudian siswa ternyata sulit memahami materi ke-3 disek karena mereka tidak memahami materi pertama dan kedua sangat mudah bagi guru tersebut untuk meminta siswanya menonton kembali materi yang telah di-upload YouTube.

Youtube telah digunkaan dalam proses belajar menagajar. Moghavvemi, Sulaiman, Kasem (2018) mengatakan bahwa Youtube diakses oleh siswa dengan berbagai alasan seperti untuk hiburan, mencari informasi, dan untuk kepentingan belajar. Lebih lanjut mereka mengatkan bahwa video Youtube menjadi mendukung pembelajaran siswa selama mereka menonton materi yang terkait dengan pembelajarannya. Almurashi (2016) bahkan mengatakan bahwa Youtube adalah salah satu madia pembeljaran yang effectif digunkan karena bisa membatu siswa dalam memahami pembelajarannya, menigkatkan pencapain belajar siswa, dan membantau memperlajari konsep yang terkait dengan materi pembelajarannya. Dalam pembeljaran Bahasa Inggris, Youtube telah dipakai dalam menignkatkan berbagai kemampuan Bahasa Ingris seperti menignkatakn kemampuan menyimak (Ayu,2017).

\section{METODE}

Pengabdian ini dibuat dengan 5 langakah yaitu,yang pertama melakukan kajian literature, melakukan wawancara, merumuskan materi dan membuat video, membuat YouTube Channel, dan mengunggah video Pembelajaran di YouTube Channel. Setelah pembuatan video maka kami mewawancarai 2 guru 
Bahasa Inggris di sekolah tersebut. Untuk mengetahui materi video maka pengabdi melakukan wawancara kepada siswa dan siswi di tempat pengabdian, focus pertanyaannya adalah:

1. Bagaimana jaringan di tempat mereka

2. Bagaimana ketersedian biaya pembelian pulsa

3. Bagaima dengan HP yang mereka miliki (pulsa internet dan kepemilikan)

4. Video pemebelajaran apa yang pernah mereka tonton

5. Apa yang mereka suka dan tidak sukai dari video tersebut

Jawaban dari pertanyaan di atas akan mejadi pertimbagan dalam pebuatan video. Hasil wawancara ini akan dikumpulkan dan disatukan kedalam poin poin penting. Selaih hal di atas maka buku pegangan pembelajaran Bahasa Inggris di Madrasah Aliyah kelas X menjadi acuan dalam pembuatan video.

\section{HASIL DAN PEMBAHASAN}

Hasil wawancara kepada 17 siswa kelas $X$ dapat diklasifikasi kedalam 4 bagian, jaringan dan pulsa internet, Penggunaan HP, Pengalaman Menonton Video Pembelajaran, dan Hal Yang mereka suka dan tidak sukai ketika menonton video pembelajaran.

\section{Jaringan dan Pulsa Internet}

Siswa-siswi mengeluhkan jaringan yang tidak stabil karena mereka tinggal jauh dari kota, tetapnya di pedesaan di daerah pegunungan. Menurut mereka hanya ada satu provider yang jaringannya bagus digunakan di daerah mereka akan tetapi beberapa siswa yang tinggal jauh tetap merasa kesulitan dengan jaringan internet.

Selain persoalan jaringan ini ada beberapa siswa mengatakan bahwa mereka tidak diberikan uang yang cukuk oleh orang tuanya untuk membeli pulsa. Sehingga mereka merasa kesulitan jika diminta untuk belajar secara online.

\section{Penggunaan HP}

Dari 17 siswa yang diwawancarai terdapat 5 siswa yang mengaku tidak memiliki HP. Mereka mengatakan orang tuanya tidak memiliki cukup uang untuk memebelikan mereka HP. Mereka belajar dengan menggunakan HP orang tua, belum lagi jika mereka harus berbagi dengan saudara-saudarinya.

\section{Pengalman Menonton Video Pembelajaran}

Semua siswa pernah menonton video pembelajaran karena beberapa guru mereka menggunakan video pembelajaran. Guru mereka mengirim link video YouTube kemudian mereka membukanya meski terkadang mereka tidak sempat mebukanya karena kehabisan pulsa internet/paket data. 


\section{Hal yang Disukai dan Tidak Disukai}

Adapun hal yang disukai berdasarkan pengalaman mereka menonton video pembelajaran adalah mereka bisa mengulang jika mereka tidak faham, mereka bisa menonton sambil santai dan mereka bisa membuka akses kapan saja mereka mau.

Adapun hal yang tidak disukai adalah 2 orang siswa yang diwawancarai mengatakan malas menonton. Kemudian mereka sangat tidak suka jika videonya panjang dan penjelasannya susah untuk difahami.

Berdasarkan hasil wawancara di atas maka pengabdi mengabil kesimpulan bahwa video yang dibuat haruslah berdurasi singkat, semudah mungkin untuk mereka fahami, dan menggunakan visual yang tidak membosankan.

Dalam pengabdian ini terdapat 6 video pembelajaran yang dibuat yang berdurasai antara 3 sampai 6 menit. Adapun topik dan percapakan di ke 6 video ini diambil dari buku pegangan siswa madrasah Aliyah kelas X.

Ke 6 video tersebut dapat ditonton di link https://www.youtube.com/channel/UCtL-i-FuJdvnI_-vJi1JAhA, adapun topiknya adalah:

a. Talking about Self https:/ $/$ www.youtube.com/watch?v=XgXMbqMXI70\&t=36s

b. What are You Going to Do Today? https://www.youtube.com/watch?v=KO8F8VGOh38

c. Announcement (https://www.youtube.com/watch?v=JqDOHkbe5p0)

d. Congratulating and complementing (https:// www.youtube.com/watch?v=nSDLsicAznQ)

e. Inspiring figure https://www.youtube.com/watch?v=DphsglnqCMU\&t=16s

f. My idol https://www.youtube.com/watch?v=DphsglnqCMU

Setelah ke 6 video selesai maka kami melakukan wawancara singkat denga kedua guru Bahasa Inggrisnya:

Guru 1 mengatakan bahwa video pembelajaran ini lebih to the point dari biasanya, lebih menarik, mudah diakses, bisa diulang, dan bisa diakses oleh siapun selain siswa sekolah. Akan tetapi ada beberapa catatan yang disampaikan oleh guru tersebut yaitu jaringan menjadi kendala di tempatnya dan sulit menjamin siswa betul-betul menonton video pembelajaran yang dikirimkan.

Adapun guru 2 mengatakan bahwa video ini sangat bagus untuk dijadikan pemantik belajar karena durasinya yang singkat, dapat diakses dan direplay kapanpun, bisa didownload dan ditonton secara offline, dan slide videonya berwarna warni dan menarik untuk dilihat. Adapun catatan dari guru 
ke 2 adalah terkadang internet tidak stabil di daerah mereka, videonya perlu diperbaiki pencahayaannya, materinya sebaiknya lebih panjang lagi berdurasi sekitar 7-10 menit.

Komentar kedua guru ini menunjukkan bahwa video yang telah dibuat oleh tim pengabdi akan memberikan manfaat dan akan digunakan ketika mereka mengajar. Adapun masukan dari kedua guru tersebut terutama durasi dan pencahayaan menjadi hal penting yang akan dilakukan dalam pebuatan video selanjutnya.

Untuk pengabdian selanjutnya ada dua hal yang bisa dilakukan yaitu yang pertama addalah mengajari guru-guru untuk membuat video pembelajaran yang menarik dan tidak mengeluarkan biaya seperti apa yang telah kami lakukan yaitu kami membuat slide lalu kami rekam dengan menggunakan zoom application secara gratis. Selain itu, perlu juga di adakan integrase video dengan evaluasi seperti misalnya memberikan pelatihan kepada guru-guru tentang cara membuat evaluasi di google form dan menginteegrasikannya dengan video yang mereka tonton. Ketika siswa telah menonton maka mereka diwajibkan untuk mengisi evaluasi online. Sehingga guru bisa mengerti tingkat pemahaman siswanya.

\section{SIMPULAN}

Pembelajaran online semakin digalakkan sebagai dampak dari penyebaran covid 19 yang datang secara tiba-tiba. Dunia pendidikan dipaksa untuk menyesuaikan dengan keadaan ini. Salah satu solusi yang kami tawarkan ditempat pengabdian kami adalah dengan membuatkan YouTube Channel yang kemudian akan kami buatkan video pembelajaran. Berdasarkan hasil wawancara kami dengan 17 siswa kelas X Madrasah Aliyah maka dapat kami simpulkan bahwa video yang dibuat seharusnya berdurasi singkat, menarik dan sesaui dengan kurikulum sekolah. Adapun masukan dari 2 guru bahasa Inggris di sekolah tersebut adalah perlu ditingkatkan kualitas videonya dan videonya perlu ditabah durasinya.

Dalam pengabdian ini diproduksi 6 video yang di unggah di YouTube Channel sekolah. Adapun topik videonya adalah Talking about Self, What are You Going to Do Today, Announcement, Congratulating and Complementing, Inspiring Figure, My idol. Ke 6 video ini bisa dikases di https://www.youtube.com/channel/UCtL-i-FuJdvnI_-vJi1JAhA.

Adapun saran untuk pengabdian selanjutnya maka kami tim pengabdi mengusulkan dua jenis pengabdian yaitu pelatihan terkait pembuatan video pembelajaran yang menarik dengan menggunakan applikasi-applikasi gratis serta pelatihan mengintegrasikan evaluasi dalam bentuk google form dengan video sehingga tingkat pemahaman siswa dari video yang ditonton bisa langsung diukur. 


\section{DAFTAR PUSTAKA}

Alursashi, W, A. (2016). The Effective Use of Youtube Videos for Teaching English Language in Classrooms as Supplementary Material at Taibah University in Alula. International Journal of English Language and Linguistics Research, Vol 4 (3), 32-47.

Ayu, L.P (2017). YouTube Videos in Teaching Listening: The benefits in Experts' Views. Research in English and Education Journal, Vo.1(2).

Chiu, T. K. F. (2017). Introducing electronic textbooks as daily-use technology in schools: A top-down adoption process. British Journal of Educational Technology, 48(2), 524-537. https:/ / doi.org/10.1111/bjet.12432

Danchikov, E. A., Prodanova, N. A., Kovalenko, Y. N., \& Bondarenko, T. G. (2021). The potential of online learning in modern conditions and its use at different levels of education. Linguistics and Culture Review, 5(S1), 578-586. https://doi.org/10.21744/lingcure.v5nS1.1442

Eccles, J. S., Midgley, C., Wigfield, A., Buchanan, C. M., Reuman, D., Flanagan, C., \& Mac Iver, D. (1997). Development during adolescence: The impact of stage-environment fit on young adolescents' experiences in schools and in families (1993). Dalam J. M. Notterman (Ed.), The evolution of psychology: Fifty years of the American Psychologist (pp. 475-501).

Ingvarson, L., Meiers, M., \& Beavis, A. (2005). Factors affecting the impact of professional development programs on teachers' knowledge, practice, student outcomes \& efficacy. Education Policy Analysis Archives, 13, 10. https://doi.org/10.14507/epaa.v13n10.2005

Moghavvemi, S., Sulaiman, A., Jaafar, N.I., Kasem, N., (2018). Social Media as a Complementary Learning Tool for Teaching and Learning: The Case of Youtube. The International Journal of Management Education, Vol 16 (1).

Selwyn, N., Nemorin, S., Bulfin, S., \& Johnson, N. (2017). Left to their own devices: The everyday realities of one-to-one classrooms. Oxford Review of Education, 43(3), 289-310. https:/ / doi.org/10.1080/03054985.2017.1305047

Starkey, L. (2019). Three dimensions of student-centred education: A framework for policy and practice. Critical Studies in Education, 60(3), 375-390. https://doi.org/10.1080/17508487.2017.1281829

UNESCO. (2020). Education: From disruption to recovery UNESCO. Diambil 13 Januari 2022, from https://en.unesco.org/covid19/educationresponse 